\title{
Soviet experience of underground coal gasification focusing on surface subsidence"
}

\author{
Yury DERBIN ${ }^{\dagger 1}$, James WALKER ${ }^{1}$, Dariusz WANATOWSKI ${ }^{1,2}$, Alec MARSHALL $^{2}$ \\ $\left({ }^{1}\right.$ Department of Civil Engineering, University of Nottingham, Ningbo 315100, China) \\ $\left({ }^{2}\right.$ Faculty of Engineering, University of Nottingham, Nottingham NG7 2RD, UK) \\ †E-mail: yury.derbin@nottingham.edu.cn
}

Received Jan. 13, 2015; Revision accepted June 12, 2015; Crosschecked Sept. 15, 2015

\begin{abstract}
Global coal mining activity is increasing due to demands for cheap energy and the availability of large coal deposits around the world; however, the risks associated with conventional coal mining activities remain relatively high. Underground coal gasification (UCG), also known as in-situ coal gasification (ISCG) is a promising alternative method of accessing energy resources derived from coal. UCG is a physical-chemical-geotechnical method of coal mining that has several advantages over traditional mining, for example, its applicability in areas where conventional mining methods are not suitable and the reduction of hazards associated with working underground. The main disadvantages of UCG are the possibility of underground water pollution and surface subsidence. This work is focused on the latter issue. A thorough understanding of subsidence issues is a crucial step to implement UCG on a wide scale. Scientists point out the scarce available data on strata deformations resulting from UCG. The former Soviet Union countries have a long history of developing the science related to UCG and experimenting with its application. However, the Soviet development occurred in relative isolation and this makes a modern review of the Soviet experience valuable. There are some literature sources dealing with Soviet UCG projects; however, they are neither up-to-date nor focus on aspects that are of particular importance to surface subsidence, including geological profiles, strata physical-mechanical properties, thermal properties of geomaterials, and temperature spreading. The goal of this work is to increase the knowledge on these aspects in the English-speaking science community.
\end{abstract}

Key words: Underground coal gasification (UCG), Surface subsidence, Thermal properties of geomaterial, Coal mining, Soviet coal basin

doi: $10.1631 /$ jzus.A1500013

Document code: A

CLC number: TD73

\section{Introduction}

Towards the end of the 20th century, coal was losing its position as the world's most prolific energy source. A number of coal mines were closed, including, for example, the Pyramiden on the archipelago of Svalbard, Norway, and the Seredeiskaya mine in the Moscow basin. However, coal has regained its position as a key energy supplier due to its

\footnotetext{
" Project supported by the European Commission's Research Fund for Coal and Steel (No. RFCR-CT-2013-00002), and PhD Scholarship awarded by the University of Nottingham Ningbo, China (D) ORCID: Yury DERBIN, http://orcid.org/0000-0002-2594-4230 (c) Zhejiang University and Springer-Verlag Berlin Heidelberg 2015
}

three advantages over oil and gas, namely lower price per energy unit, different geopolitical distribution of reserves, and a higher reserves-to-production ratio (Kavalov and Peteves, 2007). Unfortunately, the mining and burning of coal is not environmentally friendly and much of the coal in the ground is either too deep or too low in quality to be mined economically (Walter, 2007).

Underground coal gasification (UCG) is a solution at least to the deep and poor coal seams. It is one of the physical-chemical-geotechnical methods of coal mining. The method is not restricted to purely burning coal; some successful experiments on underground sulphur and shale burning have also been conducted (Miller, 1964; Arens, 1986). 
UCG has several advantages over traditional mining. Its benefits include applicability in areas where conventional mining methods are not suitable and that it reduces or even eliminates human work underground. In the simplest scheme, only two boreholes are required - one for oxygen ignition and the other for production. The product of coal gasification, synthesis gas or syngas, is easy to handle and can be used as fuel. Moreover, the method can be coupled with carbon capture and storage (CCS) by injection of $\mathrm{CO}_{2}$ in the void left after UCG. According to MacDonald (2010), UCG is the cheapest way to produce electricity in comparison with traditional mining.

\section{Surface subsidence}

Ali et al. (2012) emphasised that ground subsidence is probably the most important single obstacle to the commercialisation of UCG. This phenomenon may cause swamping the territory. Ground deformation caused by UCG has the potential for largescale detrimental effects, including initiation of flow paths between underground aquifers and damage to surface structures and buried infrastructure. Zhukov (1963a) pointed out the importance of the knowledge of surface subsidence for gas generator design and technology of the gasification. For example, Zhukov et al. (1963) argued that wells located in the middle of the trough have less possibility to be damaged.

The magnitude and form of subsidence depends on multiple aspects, such as a seam depth, its thickness and dip angle, physical-mechanical properties of the geomaterials above and under the seam, the initial stress conditions, in-situ fractures and groundwater. Skafa (1960) indicated four types of surface subsidence behaviour after UCG: no ground surface movements, smooth bending, bending with fractures, and crater (sink hole).

There are several aspects which differentiate surface subsidence during UCG from the conventional mining methods. During UCG, rocks are subject to one or both of mechanical and thermal loads. In addition, because coal burning occurs from the bottom to the top of the seam, vertical displacements are observed to occur at a slower rate compared with conventional mining (Turchaninov, 1957a). As a result, the bulking factor of the overburden rock is smaller (Turchaninov, 1957a), hence, greater surface subsidence is expected. However, during UCG the void is filled with slag and ash which can also mitigate the surface sag.

It can be concluded that subsidence during UCG is a complicated process which deserves further investigation. Tian (2013) pointed out the need for broader knowledge on high-temperature mechanical behaviour of coal, the underground temperature distribution during UCG, and field measured surface subsidence data. Zamzow (2010) argued that the subsidence behaviour from industrial scale projects was not clear. The overview on the Soviet UCG projects presented here extends the knowledge on these issues.

\section{Soviet UCG projects}

Gregg et al. (1976) summarised the Soviet experience at that time and came to the conclusion that "the amount of UCG research effort expended by the Soviets far exceeds the summation of research efforts by other nations". The detailed history of the gas and coal industry in the Soviet Union was described by Gregg et al. (1976), Antonova et al. (1990), Klimenko (2009), Matveichuk and Evdoshenko (2011), and Kopytov (2012). The history of UCG in the Soviet Union began quite early and one of the first scientists to mention the possibility of coal extraction without conventional mining was Dmitri I. MENDELEEV in the early 1880s (Mendeleev, 1939). Kuprin (1971), the famous Russian writer, mentioned the UCG process in one of his stories in 1899. This idea was accepted with great enthusiasm by Lenin (1973) and this was one of the decisive factors that drove UCG development in the Soviet Union. The Krutovskaya station was the first UCG project in the Soviet Union which was unsuccessfully conducted in 1932 (Kolesnikov, 1935; Gregg et al., 1976). Later efforts were more successful. The experience was not limited by one horizontal coal seam, but included steeply dipped coal seams (Kazak, 1965; Kreinin, 2010) and several interleaved coal seams (Lazarenko et al., 2006). The effect of permafrost on UCG has also been studied (Gusyatnikov, 1940).

Unfortunately, access to the UCG material is complicated because the papers are almost unavailable as electronic copies and not presented in the international journals because the Soviet science was 
mostly conducted with the scientists in solitude (Kapitsa, 2010). However, there is some evidence of collaboration on UCG between the Soviet Union and the USA; for example, a licence agreement with Licensintorg (the international technology exchange enterprise) of the Soviet Union and the American company 'Texas Utilities' for technical documentation and assistance in UCG (Clements, 1977). Clements (1977) reported that they had obtained documentation with data on UCG in various types of coal deposits and visited two sites in different geological basins but the outcomes could not be disclosed. There is a summary of the Soviet studies focused on surface subsidence in English done by Gregg (1979), but the author was limited by the availability of the translations from the Russian language and this makes a present review of the Soviet experience valuable.

The Soviet UCG activities were mainly focused in four basins at Angren, Moscow, Donetsk, and Kuznetsk. The first three letters of their names and the word "basin" with double "s" due to the Russian language pronunciation constitute alternative second names for the latter three basins - the Mosbass, Donbass, and Kuzbass. In the literature available in English, both names are used. Table 1 presents the UCG stations with the seam characteristics in these basins.

\section{Measurements at the sites}

Almost the same field measurements were organized for all sites. For example, in the Moscow basin, the initial vertical fractures were measured in the rock outcrops. They were generally non-uniform; however, there was some regularity of the directions (Vinogradov, 1963). Vinogradov (1963) quoted V.G. VALENTSOV based on their personal communication that the production well and the injection well connected better in the directions of the fractures. Thus, the rates of coal burning in different directions could be a hint of the orientation of the fractures. The control of surface and underground space deformation and observation of the underground space after UCG was also conducted. In the Podmoskovnaya station in 1949 , a square geodetic net of reference points were established with a spacing of 5-10 $\mathrm{m}$ that covered a gasified area of $70000 \mathrm{~m}^{2}$ along with deep reference points installed in boreholes which measured vertical deformations of different layers (Fokin, 1954). In 1952-1954, the strata were studied by new boreholes or shafts dug into the used UCG reactors (Semenenko and Turchaninov, 1957; Kazak and Semenenko, 1960). Ovchinnikov et al. (1966) reported about a geodetic net and deep reference points in five boreholes as well as excavating the gas generator after $60 \%$ coal gasification at the Yuzhno-Abinsk station. The results of the measurements will be discussed and analysed in the following sections.

\section{Strata deformations}

\subsection{Overview}

The reported magnitudes of surface subsidence resulting from UCG in different basins range from $0.5 \mathrm{~m}$ to $10 \mathrm{~m}$ (Table 2) due to different seam depths, seam inclinations (from $0^{\circ}$ to $80^{\circ}$ ), seam heights, seam widths, ash content in the coal, and different geological profiles. These factors will be discussed further in subsequent sections.

Horizontal deformations are also important to study together with settlement depths. Horizontal strata movements reduce the maximum subsidence depth but increase the size of the affected area. At the Kuznetsk basin, the tensile horizontal deformations were $+220 \mathrm{~mm} / \mathrm{m}$ and compressive horizontal deformations were $-160 \mathrm{~mm} / \mathrm{m}$ (Ovchinnikov et al., 1966). After a field study of the damaged strata using the exploitation boreholes at the Angren station, it was noticed that the horizontal displacements played a crucial role in the distortion of the boreholes (Zhukov et al., 1963). It also should be highlighted that horizontal deformations can impact on the measurements of surface settlements.

\subsection{Role of coal seam inclination in subsidence}

The seam inclination plays an important role in the type of the surface subsidence. For horizontal deposits, the bending mechanism of subsidence is typical, whereas for synclined deposits, a crater type subsidence is generally observed. According to the description of the subsidence by Turchaninov and Zabrovsky (1958) and Ovchinnikov et al. (1966), it can be concluded that the Yuzhno-Abinsk station with a $70^{\circ}$ dipped seam had a crater type subsidence with fractures propagating up to the surface. Ovchinnikov 
Table 1 Soviet UCG stations

\begin{tabular}{|c|c|c|c|c|}
\hline Station & Start date & Thickness (m) & Inclination $\left(^{\circ}\right)$ & Depth (m) \\
\hline \multicolumn{5}{|l|}{ Moscow basin } \\
\hline Krutovskaya & $1932^{* 8}$ & $1.8^{* 5}$ & $0^{* 5}$ & - \\
\hline Podmoskovnaya & $1940^{* 8}$ & $2.5^{* 5}$ & $0^{* 5}$ & $40-50^{* 2}$ \\
\hline Shatskaya & $1955^{* 4}$ & $2.6^{* 5}$ & $0^{* 5}$ & $45^{* 4}$ \\
\hline \multicolumn{5}{|l|}{ Kuznetsk basin } \\
\hline Lenin pit & $1933^{* 8}$ & - & - & - \\
\hline Yuzhno-Abinsk & $1955^{* 1}$ & $9.2-9.8^{* 7}$ & $68-70^{* 7}$ & $43^{* 3}-53^{* 7}$ \\
\hline Stalinsk & $1960^{* 8}$ & - & - & - \\
\hline Donetsk basin & & & & up to $400^{* 8}$ \\
\hline Lisichansk & $1933^{* 8}$ & - & - & \\
\hline Bobrovskiy & - & $0.75^{* 5}$ & $30-40^{* 5}$ & \\
\hline $\mathrm{K}_{8}$ & - & $1.8-2.1^{* 5}$ & $40-60^{* 5}$ & \\
\hline $1_{8}$ & - & - & $41^{* 5}$ & \\
\hline Shakhta & $1933^{* 8}$ & $0.8^{* 5}$ & - & \\
\hline $\mathrm{K}_{4}$ Rozoviy & - & $0.4^{* 5}$ & $15-18^{* 5}$ & \\
\hline Gorlovka & $1935^{* 8}$ & - & - & \\
\hline Derezovka $\mathrm{K}_{3}$ & - & $2.0^{* 5}$ & $80^{* 5}$ & \\
\hline Kamensk & $1960^{* 8}$ & - & - & \\
\hline \multicolumn{5}{|l|}{ Angren basin } \\
\hline Angren & $1960^{* 6}$ & & & \\
\hline Upper & & $0.3-3.8^{* 6}$ & - & - \\
\hline Interlayer (clay) & & $0.7-4.7^{* 6}$ & - & - \\
\hline Lower (main) & & $2.0-7.3^{* 6}$ & $5^{* 6}$ & $115-126^{* 6}$ \\
\hline
\end{tabular}

Table 2 Maximum subsidence in the different basins

\begin{tabular}{ccl}
\hline Basin & Subsidence & \multicolumn{1}{c}{ Reference } \\
\hline Moscow & $1.2 \mathrm{~m}$ & Turchaninov and Sazonov, 1958 \\
Kuznetsk & $2.2 \mathrm{~m}$ & Ovchinnikov et al., 1966 \\
& Collapses up to $10 \mathrm{~m}$ & Turchaninov and Zabrovsky, 1958 \\
Angren & $1.0 \mathrm{~m}$ & Zhukov and Orlov, 1964 \\
Donetsk & $0.5 \mathrm{~m}$ & Semenenko and Turchaninov, 1957 \\
\hline
\end{tabular}

et al. (1966) reported shear fractures at the ground surface and Zabrovsky (1959) observed gas on the surface which indicated that the fractures spread to the surface. Opposed to this, Turchaninov and Sazonov (1958) observed that at the Shatskaya station with a horizontal seam, fractures did not propagate to the surface. According to the contour maps of the subsidence by Turchaninov and Sazonov (1958), it can be concluded that the Shaskaya could be characterised by the second (smooth bending) and third (bending with fractures) types of the subsidence. At the same basin, the Moscow basin, the
Podmoskovnaya station has the same type of the subsidence according to the contour maps of the subsidence by Skafa (1960). The contour maps of the subsidence by Zhukov and Orlov (1964) show that the Angren station with a seam dipped at a small angle of $5^{\circ}$ also showed the second and third types of the subsidence.

\subsection{Role of coal seam thickness in subsidence}

The coal seam thickness influences the subsidence depth directly. This is illustrated by considering the Kuznetsk basin, where Table 1 shows that the 
thickness of the coal seam is the largest (9.2-9.8 m) and Table 2 shows that this basin also has the largest subsidence $(2.2 \mathrm{~m})$.

The coal seam thickness impacts on the height of the distressed zone that is a combination of fractured and caved zones above the gas generator, which is one of the factors affecting subsidence behaviour. Kazak and Semenenko (1960) suggested that if the coal seam is $0.4-0.5 \mathrm{~m}$, the vertical deformation of the seam roof is smooth, without failure. Skafa (1960) postulated that the height of the distressed zone for the Lisichansk station was ten times the coal seam thickness. For this station, Kazak and Semenenko (1960) reported almost the same values: the distressed zone was six to eight times the coal thickness and no failure was observed.

After laboratory experiments Zhukov (1963b) came to the conclusion that the thickness of the coal seam plays an important role in fracture opening within the caved zone. A 1:100 scale model of the Angren station showed that gasification of a coal seam up to $4 \mathrm{~m}$ thick caused fractures $15-20 \mathrm{~m}$ up from the seam, with small openings observed. For a 4-6 m thick coal seam, a net of fractures, sometimes with wide openings was observed, and for a $6-8 \mathrm{~m}$ thick coal seam, fractures with wide openings were observed. Kazak and Semenenko (1960) reported the absence of the fracture net and through fractures at the Podmoskovnaya station with a $2.5 \mathrm{~m}$ thick coal seam.

\subsection{Role of strata in subsidence}

\subsubsection{Role of weak strata in subsidence}

The existence of a weak strata decreases the time of the response of the ground surface to the UCG. At the Shatskaya station with weak strata (refer to the borehole $\log$ in Table 3), the first surface subsidence was observed on the 34th day after ignition (Turchaninov and Sazonov, 1958). At the Yuzhno-Abinsk station with mostly rock material profile, the first surface deformation was noticed eight months after ignition (Ovchinnikov et al., 1966).

\subsubsection{Role of sand in subsidence}

The gasified area at the Shatskaya station was further spread from the production wells due to the presence of sand in the roof and floor of the seam, which conducted oxygen and increased the area of the burn (Turchaninov and Sazonov, 1958). This distance was wider at the Shatskaya station $(15 \mathrm{~m})$ than that at the Podmoskovnaya station $(6-8 \mathrm{~m})$ (Turchaninov and Sazonov, 1958). However, the depths of the surface subsidence for both of these stations (in the Moscow basin) do not differ significantly.

Table 3 Borehole $\log$ at the Shatskaya station (Turchaninov and Sazonov, 1958)

\begin{tabular}{cccc}
\hline $\begin{array}{c}\text { Mean } \\
\text { depth }(\mathrm{m})\end{array}$ & $\begin{array}{c}\text { Thickness } \\
(\mathrm{m})\end{array}$ & Geomaterial & Aquifer \\
\hline 4 & $2.0-6.0$ & Loam & \\
14 & $2.0-7.0$ & Clay & \\
18 & $2.0-6.0$ & Limestone & Aleksinsky \\
21 & $2.0-3.0$ & Clay & \\
23 & $1.0-2.0$ & Limestone & Upper- \\
& & & Tulsky \\
31 & $7.0-10.0$ & Clay & \\
35 & $3.0-4.0$ & Limestone & Middle- \\
& & & Tulsky \\
37 & $1.5-3.0$ & Clay & \\
39 & $1.0-2.5$ & Limestone & Low-Tulsky \\
41 & $1.0-2.0$ & Clay & \\
43 & $1.0-3.0$ & Sand & Above coal \\
45 & $2.0-4.0$ & Coal & \\
& $0.2-0.4$ & Soil & Coal \\
48 & $1.6-2.5$ & Coal & \\
51 & $2.0-4.0$ & Clay & \\
52 & $1.0-2.0$ & Sand & Under coal \\
54 & $2.0-2.5$ & Limestone & Uspensky \\
\hline
\end{tabular}

\subsubsection{Role of limestone in subsidence}

A layer of limestone (being relatively strong) above the burn tends to smoothen the subsidence trough; however, the state of the limestone is also important. The Shatskaya and Podmoskovnaya stations are in the same basin. The profile of the Shatskaya station (see the borehole log in Table 3) includes more limestone (24\% of the vertical profile) whereas the Podmoskovnaya station has a vertical profile that includes only $10 \%$ limestone (Turchaninov and Sazonov, 1958). The schematic borehole log given by Semenenko (1965) shows that the locations of the limestone are at mean depths between $19.0 \mathrm{~m}$ and $30.0 \mathrm{~m}$, which are $18 \mathrm{~m}$ and $29 \mathrm{~m}$ above the coal seam. Turchaninov (1957b) did not notice any significant difference between these sites and concluded that the limestone did not influence the trough development because it was weakened by fractures. For 
the Lisichansk station, Kazak (1965) presented three roof borehole logs from the Donetsk basin (Table 4): one was before UCG and the other two were after. Limestone is presented along the whole profile and contributes to the shallow subsidence of $0.5 \mathrm{~m}$ (Semenenko and Turchaninov, 1957). According to the contour map of the subsidence by Semenenko and Turchaninov (1957), a smooth subsidence trough was observed. The difference between Boreholes 2 and 3 will be discussed later.

\subsection{Rate of surface subsidence}

The rate at which surface subsidence occurs (typically in $\mathrm{mm} /$ day) is important because it can provide a hint to how the UCG process has advanced and organize mitigation measures to minimize the effect of subsidence on near-surface structures and infrastructure. The subsidence velocity can also give an idea of the overburden strata's bulking factors.

A strong overburden stratum can reduce the subsidence velocity. In the Moscow basin with weak strata, the subsidence velocity was the highest when compared with the other three basins. At the Shatskaya station, the mean subsidence velocity was $25 \mathrm{~mm} /$ day with a maximum of $40 \mathrm{~mm} /$ day (Turchaninov and Sazonov, 1958). In the Kuznetsk basin, the maximum subsidence velocity reached the mean velocity in the Moscow basin-25 mm/day (Ovchinnikov et al., 1966). In both basins the depths of the coal seams were approximately $50 \mathrm{~m}$ below the surface but the Kuznetsk basin has stronger strata than the Moscow basin.

The subsidence rate also reduces with an increase in depth of the coal seam. At the Angren site, the coal seam is at a depth of $110-120 \mathrm{~m}$ and the subsidence was slower than that in the basins described above, with a maximum of $5 \mathrm{~mm}$ /day (Zhukov et al., 1963). In the Donetsk basin, the subsidence velocity was the slowest, $1 \mathrm{~mm}$ /day (Semenenko and Turchaninov, 1957). Possibly, this is because it has the deepest coal seam (up to $400 \mathrm{~m}$ ).

The presence of the strong limestone in the profile causes a constant subsidence velocity over time. Table 5 presents two borehole logs which are located at a distance of $450 \mathrm{~m}$ from each other in the Angren basin. Table 5 shows that the location of the limestone is far away from the failure zone and near the surface in the Angren basin. However, the process of the surface subsidence had a constant velocity, and this is believed to be due to the limestone layer (Zhukov et al., 1963).

Table 4 Bottom height of the layers above the coal seam at the Lisichansk station (Kazak, 1965)

\begin{tabular}{cccc}
\hline & & \multicolumn{2}{c}{ Bottom height $(\mathrm{m})$} \\
\cline { 2 - 4 } Geomaterial & Before UCG, & \multicolumn{2}{c}{ After UCG } \\
\cline { 2 - 4 } & Borehole 1 & Borehole 2 & Borehole 3 \\
\cline { 2 - 4 } Limestone & 14.40 & 13.55 & 13.40 \\
Shale & 12.07 & 10.74 & 9.78 \\
Shale with limestone & 10.13 & 9.80 & 8.44 \\
Shale & 9.19 & 8.88 & 8.27 \\
Coal & 9.04 & 8.70 & 6.00 \\
Shale with limestone & 7.15 & 6.75 & 5.46 \\
Shale with higher amount of limestone & 6.72 & 6.31 & 5.14 \\
Sandy shale-shale & 6.22 & 5.95 & 5.04 \\
Sandy shale & 6.12 & 5.85 & 3.93 \\
Sandy shale-shale & 4.36 & 4.03 & 3.67 \\
Shale & 4.21 & 3.93 & 3.07 \\
Sandy shale-shale & 3.24 & 3.15 & 2.89 \\
Shale & 2.76 & 2.42 & 2.71 \\
Limestone & 2.61 & 2.30 & 2.08 \\
Shale & 1.73 & $1.92^{* 1}$ & $1.70^{* 1}$ \\
Sandy shale-shale & & $1.42^{* 2}$ & $1.40^{* 2}$ \\
Coal/Slag & 1.43 & $1.12^{* 2}$ & $0.37^{* 3}$ \\
\hline
\end{tabular}

\footnotetext{
${ }^{{ }_{1}}$ Warmed; ${ }^{* 2}$ Fired and fractured; ${ }^{* 3}$ Failed
} 
Table 5 Two borehole logs in the Angren basin (Zhukov et al., 1963)

\begin{tabular}{|c|c|c|}
\hline \multirow{2}{*}{ Geomaterial } & \multicolumn{2}{|c|}{ Depth (m) } \\
\hline & Borehole 1 & Borehole 2 \\
\hline Clay & 0 & 0 \\
\hline Limestone & 17 & 13 \\
\hline Sandstone & - & 27 \\
\hline Clay & - & 34 \\
\hline Sandstone & 31.5 & 39 \\
\hline Clay & 39.5 & 45.5 \\
\hline Sandstone & 46 & 52 \\
\hline Clay & 53 & 58 \\
\hline Sandstone & 59.5 & 62.5 \\
\hline Clay & 65.5 & 67 \\
\hline Sandstone & 70.5 & 68.5 \\
\hline Clay & 74.5 & 72.5 \\
\hline Sandstone & 76.5 & 74.5 \\
\hline Kaolinite & 80 & 78 \\
\hline Sandstone & 87 & 85 \\
\hline Kaolinite & 89 & 86.5 \\
\hline Sandstone & 101.5 & 99 \\
\hline Kaolinite & 103.5 & 101 \\
\hline Sandstone & 108.5 & 105.5 \\
\hline Clay & 112 & 109 \\
\hline Sandstone & 121 & 120 \\
\hline Clay & 122 & - \\
\hline Sandstone & 123.5 & - \\
\hline Clay & 122 & 121 \\
\hline Sandstone & 126.5 & 124 \\
\hline Clay & 128 & 128 \\
\hline Coal & 130 & 131 \\
\hline
\end{tabular}

\section{Impact of coal burning in-situ}

\subsection{Thermal geomaterial conductivity}

The main differences between UCG and conventional coal mining are exposure of the geomaterial to the high temperatures and the products of burning that are left in the void. According to Turchaninov (1956), the temperature was more than $1500{ }^{\circ} \mathrm{C}$ in the generators in the Donetsk basin. However, Turchaninov (1956) believed the temperature was lower in the Moscow basin due to the coal's lower heat conductivity because the air was injected instead of oxygen.

The high temperature impact of UCG is a complicated process. The information about thermal geomaterial conductivity, calculation of heat losses for heating wet soil, and strata physical-mechanical properties under thermal conditions will be discussed. The ash properties will be also considered.

Semenenko and Turchaninov (1957) claimed UCG heats rock and soil over only a relatively small distance away from the UCG generator. Russo and Kazak (1958) agreed with this fact but pointed out that the spread of the heat mainly occurs due to the convection of hot gas through the fractures that appear near the generator.

The energy conductivity of the coal in the seam is very small (Kolesnikov, 1935), but the real conductivity could be much higher due to fractures. Kolesnikov (1935) reported a temperature decrease of $10{ }^{\circ} \mathrm{C} / \mathrm{m}$ at the Moscow basin. Kazak and Semenenko (1960) gave some data on soil heating at the Lisichansk UCG station.

Fig. 1 shows that the temperature reduces to less than $100{ }^{\circ} \mathrm{C}$ at a distance of $3 \mathrm{~m}$ above the seam and $4 \mathrm{~m}$ below (the lowest depth where measurements were conducted). At a distance of $10 \mathrm{~m}$ above the seam, the thermal effects from UCG were not observed.

Kazak et al. (1990) observed at the YuzhnoAbinskaya station that the temperature dropped sharply from $1000{ }^{\circ} \mathrm{C}$ to $400{ }^{\circ} \mathrm{C}$ in the lower, nonstructured, part of the caved zone, then the geomaterial fell from the roof to the bottom of the seam, and the temperature does not change significantly for the rest of the caved zone. Kazak et al. (1990) explained that the geomaterial of the lower part falling

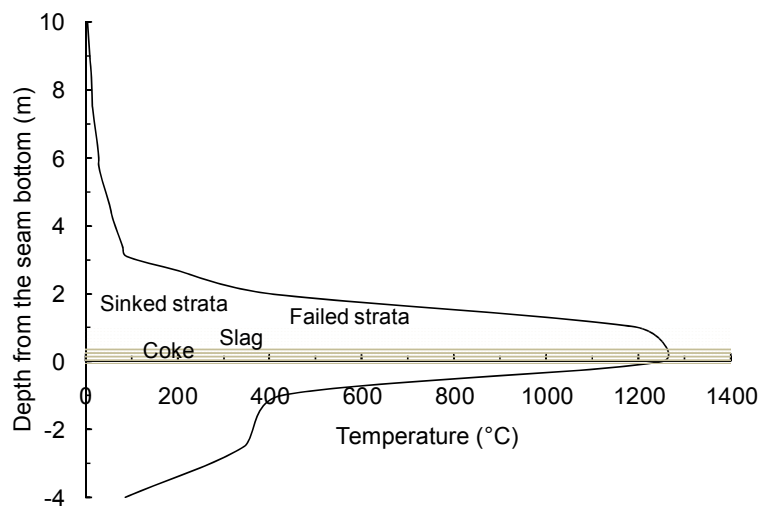

Fig. 1 Distribution of soil temperature after UCG at the Lisichansk station (modified from (Kazak and Semenenko, 1960)) 
from the roof piece by piece is exposed to direct burning but the other material is subsequently heated due to conduction. Kazak et al. (1990) suggested an equation for heat loss during conduction:

$$
\frac{Q_{1}+Q_{2}}{Q}=\frac{350}{q_{\mathrm{y}}} \cdot \frac{m_{\mathrm{c}}}{m}+\frac{100.7 \sqrt{l}}{m \sqrt{v} q_{\mathrm{y}}},
$$

where $Q_{1}$ represents the convective heat losses (J), $Q_{2}$ represents the conductive heat losses (J), $Q$ represents the general heat produced by UCG $(\mathrm{J}), m_{\mathrm{c}}$ is the thickness of the isothermic area (m), $l$ is the width of the isothermic area $(\mathrm{m}), m$ is the thickness of the gasified area (m), $v$ is the velocity of the face development ( $\mathrm{m} /$ day), and $q_{\mathrm{y}}$ is the heat of the coal burn $\left(\mathrm{J} / \mathrm{m}^{3}\right)$.

\subsection{Calculation of heat loss due to evaporation}

The magnitude of heat loss due to evaporation in wet ground during UCG has been considered. Based on the assumption by Stefan (Riemann and Weber, 1927), Lykov and Pomerantchev (1935) analytically showed that the evaporation surface would expand into the soil according to the equation:

$$
s=\alpha \sqrt{t}
$$

where $t$ represents the time (h), and $\alpha$ represents a coefficient which depends on the thermal heat conductivity coefficient, dry soil density, absolute soil moisture, soil surface temperature, soil temperature, and vaporisation temperature.

After modification, it is possible to obtain Eq. (3) to determine the amount of the evaporated water $\left(\mathrm{kg} / \mathrm{m}^{2}\right)$.

$$
w=\alpha \rho_{1} W_{\mathrm{a}} \sqrt{t},
$$

where $\rho_{1}$ represents the dry soil density $\left(\mathrm{kg} / \mathrm{m}^{3}\right)$, and $W_{\mathrm{a}}$ represents the absolute soil moisture.

In two calculations involving heat loss in soils, $\alpha$ was taken as 0.0455 and 0.0480 . These values were estimated based on mathematical calculations using the parameters characterising the heating technique and for the prescribed physical constants.

\subsection{Strata under thermal impact}

During UCG, the strata are subject to both mechanical and thermal loads. Gerdov (1940) argued that the thermal impact on different strata could be very different and each case needs to be studied individually.

Under high temperatures, the strength of the geomaterial can either increase or decrease. Generally, over the range of the UCG temperatures, the laboratory tests show that the geomaterial strength increases. The uniaxial compression strength of shale at the Lisichansk station was shown to increase from 7.7 MPa to 40.7 MPa after UCG (Russo and Kazak, 1958). According to Russo and Kazak (1958), the strength of a sample of shale with high $\mathrm{SiO}_{2}$ from the Lisichansk station increased from $24.2 \mathrm{MPa}$ at $0{ }^{\circ} \mathrm{C}$ to 87.0 MPa at $900{ }^{\circ} \mathrm{C}$.

Fig. 2 shows the relationship between temperature and strength of clay at the Mosbass, and rock of the Donbass and Kuzbass. The common trend is that mainly the strength increases with the temperature until a particular temperature, for example, $800^{\circ} \mathrm{C}$ for the sandy clay and $1000^{\circ} \mathrm{C}$ for the organic clay with high coal content, so-called coaly clay. After these temperatures, the strength decreases due to the agglomeration of the soil particles (Semenenko and Turchaninov, 1957). The strength of the sandy clay increases more rapidly until $400{ }^{\circ} \mathrm{C}$ due to water evaporation (Semenenko and Turchaninov, 1957). In Fig. 2, the rocks increase in strength less than the

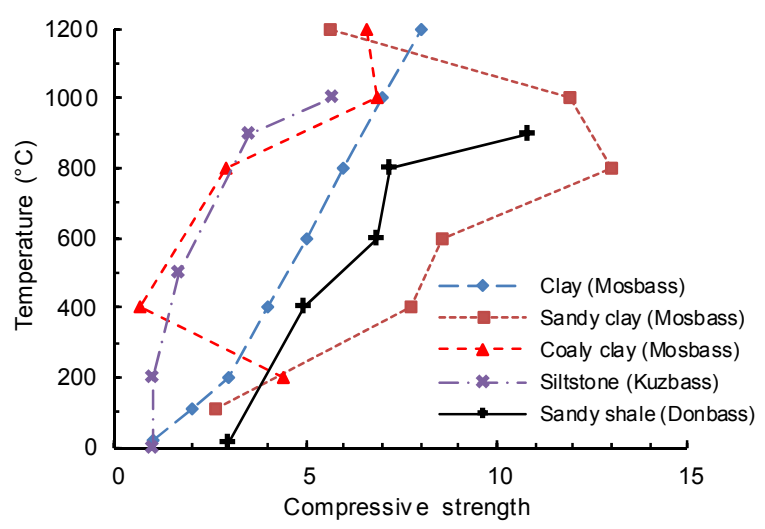

Fig. 2 Compressive strength under different temperatures (for soils modified from (Semenenko and Turchaninov, 1957), the unit of compressive strength is MPa; for rock modified from (Antonova et al., 1990), the unit of compressive strength is $\times 10 \mathrm{MPa}$ ) 
soils; however, the coaly clay has the opposite behaviour. At the beginning of burning, the strength decreases until $400{ }^{\circ} \mathrm{C}$ is reached because the coal particles burn and fracture (Semenenko and Turchaninov, 1957). This agrees with Ruschinsky (1952) who concluded that the compressive strength of the Moscow basin coal reduces from 1.61-2.02 MPa to 0.70-0.75 MPa under the thermal impact and after coal burning, and the left ash has strength of only 0.02-0.04 MPa. Fig. 2 also shows the strength of the clay increases almost linearly with temperature. Semenenko et al. (1952) pointed out that the clay lost its plastic properties under high temperatures.

\subsection{Change in volume}

The other effect of the thermal impact on the strata is volume change. This expansion or contraction in the strata volume can markedly reduce or increase surface subsidence. Table 5 shows two different borehole logs after a UCG event. Borehole 2 has $0.75 \mathrm{~m}$ of slag, and borehole 3 has $1.4 \mathrm{~m}$ of slag. The deformation of the strata over borehole 3 was insignificant and failure was not observed (Kazak, 1965). Kreinin and Kogan (1963) observed that for the coal, the highest rate of the increase in volume was at $350-450{ }^{\circ} \mathrm{C}$.

Gerdov (1940) conducted several thermal experiments on the strata samples from the Donetsk and the Moscow basins. The cylindrical samples, $50 \mathrm{~mm}$ long and $35 \mathrm{~mm}$ in diameter, were kept in a stove and under no load as well as a constant load of 0.5 MPa. Gerdov (1940) came to the following conclusions:

1. The Donetsk basin limestone. The $600 \mathrm{~mm} \times$ $45 \mathrm{~mm} \times 55 \mathrm{~mm}$ sample starts sagging while set on two supports without load at $1295^{\circ} \mathrm{C}$. At $1365{ }^{\circ} \mathrm{C}$ sagging reaches $50 \mathrm{~mm}$. The sample becomes powder $(\mathrm{CaO})$ at $1395{ }^{\circ} \mathrm{C}$ and loses about $50 \%$ volume.

2. The Moscow basin clay. The melting temperature is quite high at $1730{ }^{\circ} \mathrm{C}$ and an initial soil increase in volume is observed at $600-800{ }^{\circ} \mathrm{C}$.

3. The Donetsk basin shale starts deforming at $860-940{ }^{\circ} \mathrm{C}$ under a constant load of $0.5 \mathrm{MPa}$ with plastic deformation starting at $1000-1140^{\circ} \mathrm{C}$. The deformation ends at $1030-1250^{\circ} \mathrm{C}$, and at 1470 $1580{ }^{\circ} \mathrm{C}$ the rock melts. The shale of the Moscow basin starts deforming, increasing in volume at almost the same temperature of $970{ }^{\circ} \mathrm{C}$. Fractures appear at $970-1100^{\circ} \mathrm{C}$ without exfoliation, and melting starts earlier at $1000^{\circ} \mathrm{C}$.

The laboratory experiments by Russo and Kazak (1958) showed that the coefficient of the volume increase, the so-called swelling coefficient, for the shale of the Lisichansk station rises non-linearly over $1000-1200{ }^{\circ} \mathrm{C}$ (Fig. 3) and the plastic state is reached at $1200^{\circ} \mathrm{C}$. The swelling coefficient can be as high as 2.2. Moreover, the $i n-s i t u$ volume increase is greater than the theoretical extrapolation of this value because of the increase of fractures and porosity in the bulk material (Russo and Kazak, 1958).

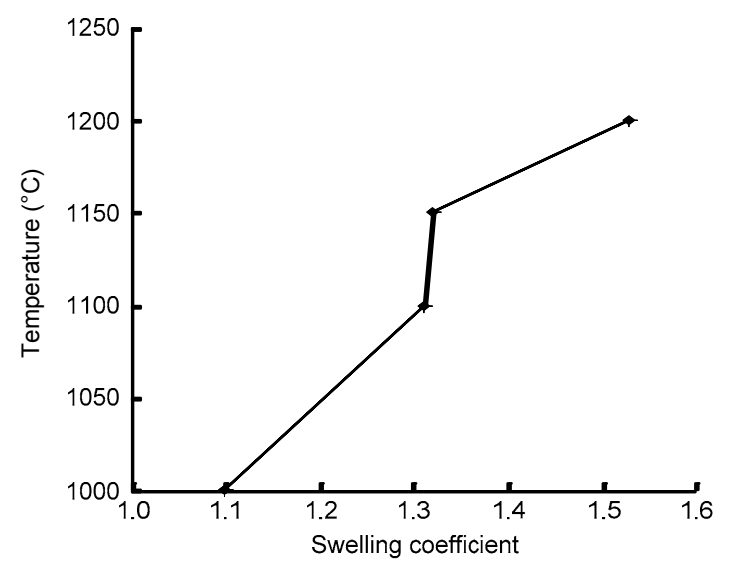

Fig. 3 Swelling coefficient under different temperatures (modified from (Russo and Kazak, 1958))

Porosity is partly responsible for the volume change in a geomaterial which is an important factor of soil deformation (Chen et al., 2014). Fig. 4 shows that within the sandy clay (the Moscow basin) porosity does not change greatly with increasing temperature. However, the clay porosity increases at low temperatures $\left(200-600{ }^{\circ} \mathrm{C}\right)$ and decreases at high temperatures $\left(600-1200{ }^{\circ} \mathrm{C}\right)$.

\subsection{Role of the ash in subsidence}

One more feature of UCG is that the void is partly filled with ash after the underground burn of the coal. Turchaninov (1956) pointed out that the physical-mechanical ash properties can have an impact on the ground surface subsidence. According to Gregg et al. (1976), the coal in the Moscow basin has the highest ash content of up to $60 \%$, whereas the others have approximately $10 \%$ ash content. Turchaninov (1956) gave ash shrinkage vs. pressure 
curves (Fig. 5) for two samples of $14.1 \%$ and $21.0 \%$ ash contents taken at the Podmoskovnaya station and the Moscow basin.

Fig. 5 shows that ash shrinkage decreases with pressure, and at pressures greater than $1 \mathrm{MPa}$ very little change in volume occurs. Turchaninov (1956) provided Eq. (4) to determine the volume of remaining ash $\left(V_{\text {ash }}\right)$ after the UCG burn based on experimental results.

$$
V_{\text {ash }}=0.014 A_{\mathrm{c}} V_{\mathrm{y}},
$$

where $A_{\mathrm{c}}$ is the ash content in the coal (\%), and $V_{\mathrm{y}}$ is the volume of the gasified coal $\left(\mathrm{m}^{3}\right)$.

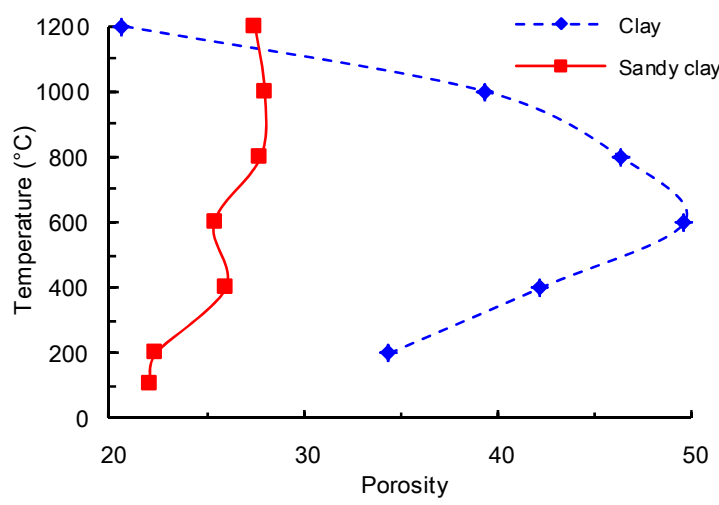

Fig. 4 Changes of porosity under different temperatures (modified from (Semenenko and Turchaninov, 1957))

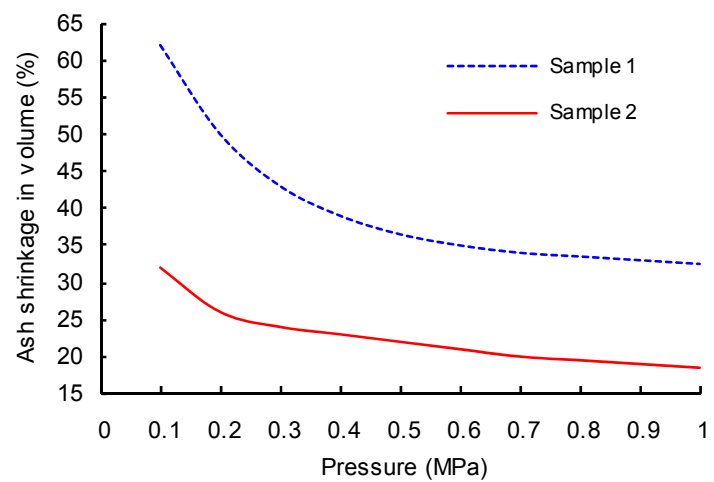

Fig. 5 Ash shrinkage vs. pressure (modified from (Turchaninov, 1956))

Sample 1: $A_{\mathrm{c}}=21.0 \%$; Sample 2: $A_{\mathrm{c}}=14.1 \%$

The pressure on the goaf increases with the distance from the face during conventional mining. In Fig. 6, there is dependence between the pressure and the distance from the face after failure at the Moscow basin. Turchaninov (1956) suggested that it is the same for UCG but the transition should be smoother.

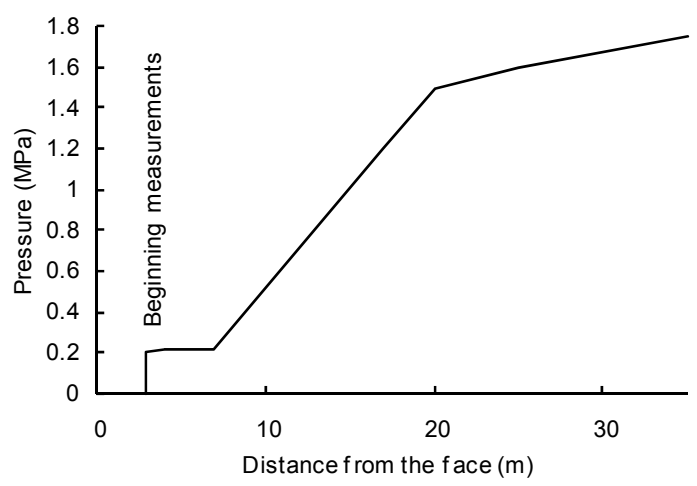

Fig. 6 Pressure vs. the distance from the face (modified from (Ruschinsky, 1952))

\subsection{Groundwater}

The temperature and mineralization of the groundwater can be a key to the UCG thermal effect and it should be investigated thoroughly (Kreinin et al., 1991). According to Kreinin et al. (1991), the UCG area has an abnormally high water temperature and this can be seen 20 years after the burn at the Yuzhno-Abinsk UCG station. Moreover, higher groundwater mineralization was noticed near the UCG reactor (Kreinin et al., 1991).

\section{Conclusions}

This paper has provided a review of some literatures describing the Soviet experience of the UCG, with the main emphasis on ground movements. The main source of the literatures was the National Library of Russia in Saint Petersburg. The papers reviewed were rather old, some being issued before World War II, and most of them are only available as hard copies. Two additional libraries could be useful sources to obtain further information: the Russian State Library in Moscow and the Library of the Russian Academy of Sciences in Saint Petersburg (access is limited). In this paper, the focus is on early work on UCG because more recent developments have shifted from the countries of the former Soviet Union to other regions mainly due to discovery of the large natural gas deposits in the Soviet Union. Today, there is only 
one station, Angren station in Uzbekistan still operated by Yerostigaz, a subsidiary of Linc Energy, and recently it has been announced that Coal Bed Methane Partners, a subsidiary of Red Mountain Energy, launched the first UCG project in Russia for many years.

\section{References}

Ali, S.M., Pattanayal, P., Shubhra, 2012. Underground coal gasification techniques, problems and its solutions. International Journal of Engineering and Innovative Technology, 2(3):129-134.

Antonova, R.I., Bezhanishvili, A.I., Blinderman, M.S., et al., 1990. Underground Coal Gasification. Central Research Institute of Economics and Scientific-Technical Information of Coal Industry Press, Moscow (in Russian).

Arens, V.Z., 1986. Mining by Boreholes. Nedra, Moscow (in Russian).

Chen, X.X., Luo, Z.J., Zhou, S.L., 2014. Influences of soil hydraulic and mechanical parameters on land subsidence and ground fissures caused by groundwater exploitation. Journal of Hydrodynamics, Ser. B, 26(1):155-164. [doi:10.1016/S1001-6058(14)60018-4]

Clements, B.R., 1977. Progress report for the Texas utilities UCG program. Proceedings of the 3rd Annual Underground Coal Conversion Symposium, Lawrence Livermore Laboratory, California, USA, p.81-82.

Fokin, D.A., 1954. Implementation of deep reference points for studying strata deformation at the Podmoskovnaya station. Journal of Underground Coal Gasification, (3):5-12 (in Russian).

Gerdov, M.A., 1940. Some results of the thermal study of the strata bearing coal seams. Bulletin on the Issues of Underground Coal Gasification, (1):1-23 (in Russian).

Gregg, D.W., 1979. Ground subsidence resulting from underground gasification of coal. In Situ, 3(1):53-81.

Gregg, D.W., Hill, R.W., Olness, D.U., 1976. Overview of the Soviet effort in underground gasification of coal. Lawrence Livermore Laboratory, California, USA.

Gusyatnikov, S.P., 1940. Permafrost and underground coal gasification. Bulletin on the Issues of Underground Coal Gasification, (1) (in Russian).

Kapitsa, S.P., 2010. What should be done with the science? Lecture, Moscow (in Russian).

Kavalov, B., Peteves, S.D., 2007. The Future of Coal. DG JRC Institute for Energy, the Netherlands (in Russian).

Kazak, V.N., 1965. Mechanism of rock performance under underground coal gasification of the thin, slightly sloping and sloping coal seams. Scientific Work of All-Soviet Research Institute of Underground Coal Gasification, (13):43-52 (in Russian).

Kazak, V.N., Semenenko, D.K., 1960. Study of geological factors determining the underground coal gasification process. Management of the seam roof under Underground coal gasification. Scientific Work of All-Soviet
Research Institute of Underground Coal Gasification, (1):72-82 (in Russian).

Kazak, V.N., Kapralov, V.K., Kreinin, E.V., 1990. Ways of reducing heat losses under underground coal gasification. Physical-Chemical Problems of Mining, (6):91-96 (in Russian)

Klimenko, A.Y., 2009. Early ideas in underground coal gasification and their evolution. Energies, 2(2):456-476. [doi:10.3390/en20200456]

Kolesnikov, P.T., 1935. To the question about stratum thermal conductivity. Journal of Underground Coal Gasification, (2):9-11 (in Russian).

Kopytov, V.V., 2012. Gasification of Condensed Fuel: Retrospective Review, State-of-the-art Affairs and Development Prospects. Infra-Engineering Press, Moscow (in Russian).

Kreinin, E.V., 2010. Underground Coal Gasification: Bases of Theory and Practice, Innovations. Korina-ofset Press, Moscow (in Russian).

Kreinin, E.V., Kogan, M.Y., 1963. Heaving of Southern Abinsk coal in the canal: underground coal gasification. Scientific Work of All-Soviet Research Institute of Underground Coal Gasification, (11):38-46 (in Russian).

Kreinin, E.V., Antonova, R.I., Dvornokova, Y.V., et al., 1991. Underground coal gasification and preservation of the environment. Journal of the Skochinski Mining Institute, (1):199-207 (in Russian).

Kuprin, A.I., 1971. In the Earth Interior. Collection in 9 Volumes, Khud. Literatura Press, Moscow (in Russian).

Lazarenko, S.N., Mazakin, V.P., Trizno, S.K., et al., 2006. Underground coal gasification in Kuzbass: new possibilities. Institute of Coal and Coalchemistry SO RAN, Kemerovo, Russia (in Russian).

Lenin, V.I., 1973. Full collection of the essays. Politizdat, Moscow (in Russian).

Lykov, A.V., Pomerantchev, A.A., 1935. Calculation of heat losses for heating the wet soil under underground coal gasification. Journal of Underground Coal Gasification, (9):3-14 (in Russian).

MacDonald, M., 2010. UK Electricity Generation Costs Update. Mott MacDonald, UK.

Matveichuk, A.A., Evdoshenko, Y.V., 2011. The origins of the Russian gas industry. In: 1811-1945 Historical Essays. Granitsa, Moscow (in Russian).

Mendeleev, D.I., 1939. Essays, Volume 1. Literaturnoe Nasledie Press, Leningrad, Russia (in Russian).

Miller, W.S., 1964. Burning Process for Recovering Sulfur from the Earth. US Patent 3131914.

Ovchinnikov, V., Tyutin, F., Semenenko, D., et al., 1966. Features of the rock deformation and its performance under underground gasification of the steep coal seam at the Kuznetsk basin (Kuzbass). Underground Coal Gasification at the Kuzbass, 1:130-146 (in Russian).

Riemann, B., Weber, H., 1927. Differentialgleichungen der Physik. Ph. Frank and R. von Mises, Braunschweig, (2) (in German). 
Ruschinsky, M.V., 1952. Changes of the rock pressure in the longwall face of the mine \#33 of Moscow coal. Journal of the Skochinski Mining Institute, (7):12-17 (in Russian).

Russo, Y.V., Kazak, V.N., 1958. Changes of physicalmechanical properties of the coal seam roof under underground coal gasification. Journal of Underground Coal Gasification, (4):36-40 (in Russian).

Semenenko, D.K., 1965. About rock loosening under underground coal gasification at the Podmoskovny basin. Scientific Work of All-Soviet Research Institute of Underground Coal Gasification, 13:32-35 (in Russian).

Semenenko, D.K., Turchaninov, I.A., 1957. Rock performance under underground coal gasification. Journal of Underground Coal Gasification, (3):31-39 (in Russian).

Semenenko, D.K., Fokin, D.A., Turchaninov, I.A., 1952. Study of strata behaviour during UCG. Scientifictechnical Report, VNII Podzengasa (in Russian).

Skafa, P.V., 1960. Underground Coal Gasification. Gosgortechizdat, Moscow (in Russian).

Tian, H., 2013. Development of a Thermo-mechanical Model for Rocks Exposed to High Temperatures during Underground Coal Gasification. PhD Thesis, RWTH Aachen University, Germany.

Turchaninov, I.A., 1956. About some physical-mechanical properties of the ash residue under underground coal gasification at the Podmoskovny basin. Journal of Underground Coal Gasification, (7):55-58 (in Russian).

Turchaninov, I.A., 1957a. About nature of underground coal gasification and deformation of the rock under underground coal gasification at the Podmoskovny basin. Journal of Underground Coal Gasification, (2):74-78 (in Russian).

Turchaninov, I.A., 1957b. Ways of the solution for management of the top under underground coal gasification. Journal of Underground Coal Gasification, (2):39-41 (in Russian).

Turchaninov, I.A., Zabrovsky, A.S., 1958. Rock deformation and its influence on the process of underground gasification of the thick and steep coal seam. Journal of Underground Coal Gasification, (2):7-11 (in Russian).

Turchaninov, I.A., Sazonov, V.A., 1958. Some features of coal seam gasification and shifting overburden rock under underground coal gasification at the Shatskaya station. Journal of Underground Coal Gasification, (3):11-16 (in Russian).

Vinogradov, B.G., 1963. About nature of rock fracturing in the area of the Shatskaya station. Underground coal gasification. Scientific Work of All-Soviet Research Institute of Underground Coal Gasification, (10):82-90 (in Russian).

Walter, K., 2007. Fire in the hole. Science \& Technology,
Lawrence Livermore National Laboratory, (4):12-18.

Zabrovsky, A.S., 1959. Conditions of seal saving of the underground gas generators in the steep medium-thickness seams. Journal of Underground Coal Gasification, (3):6-10 (in Russian).

Zamzow, K.L., 2010. Underground coal gasification: history, environmental issues, and the proposed project at Beluga. Center for Science in Public Participation, Alaska.

Zhukov, V.V., 1963a. About possibility of interpretation of gasification of thick coal seam of Angrensk field by ground subsidence. Scientific Work of All-Soviet Research Institute of Underground Coal Gasification, (11):47-53 (in Russian).

Zhukov, V.V., 1963b. Preliminary results of the study of the rock massif disturbance during excavation of the Angren coal seam with different thicknesses. Scientific Work of All-Soviet Research Institute of Underground Coal Gasification, (10):77-82 (in Russian).

Zhukov, V.V., Orlov, G.V., 1964. Ground subsidence under underground gasification of the coal seam at the industrial gas generator \#3 at the Angren station "Podzemgaz". Scientific Work of All-Soviet Research Institute of Underground Coal Gasification, (12):68-74 (in Russian).

Zhukov, V.V., Ovchinnikov, V., Loshkin, E.L., et al., 1963. To the question about influence of strata movement under underground gasification of the Angren coal seam on disturbance of the casing pipes of the underground gas generators boreholes. Scientific Work of All-Soviet Research Institute of Underground Coal Gasification, (10):85-90 (in Russian).

\section{中文概要}

\section{题 目: 综述前苏联关于地表沉陷的煤炭地下气化经验}

概 要: 1. 相比于传统的煤矿开采方法, 煤炭地下气化的 适用范围更广, 但同时也可能引起地下水污染和 地表沉陷。2. 前苏联在煤炭地下气化方面拥有一 段很长的研究和使用历史, 由于当时的国际环 境, 前苏联的研究相对比较封闭, 所以对其研究 成果的综述目前仍然很有价值。3. 综述了不同煤 层参数 (如煤层深度、倾斜度、高度、宽度、含 灰量和地质剖面等) 和气化燃烧相关参数 (如岩 土材料导热性、热损耗、热冲击和体积变化等) 与地表沉陷的相关性研究。

关键词: 煤炭地下气化; 地表沉陷; 岩土材料热性能; 煤 矿开采; 苏联煤田 